\title{
Health impact assessment by ingestion of polluted soil/sediment
}

The Mining-Geology-Petroleum Engineering Bulletin

UDC: 504

DOI: $10.17794 /$ rgn.2016.2.3

Original scientific paper

\author{
Ines Tomašek ${ }^{1}$, Marta Mileusnić ${ }^{1}$, Andreja Leboš Pavunc ${ }^{2}$ \\ ${ }^{1}$ University of Zagreb, Faculty of Mining, Geology and Petroleum Engineering, Department of Mineralogy, Petrology and Mineral Resources, \\ Pierottijeva 6, HR-10000 Zagreb, Croatia \\ ${ }^{2}$ University of Zagreb, Faculty of Food Technology and Biotechnology, Department of Biochemical Engineering, Pierottijeva 6, HR-10000 Zagreb, \\ Croatia
}

\begin{abstract}
Potentially toxic elements (PTEs) pose a threat to human health as they can easily enter the human body via ingestion of polluted soil/sediment. In order to estimate the bioavailability and assess the health impact on people, measurement of the oral bioaccessibility of a pollutant is crucial. Various laboratory based in vitro tests which mimic human gastrointestinal tract conditions can be used. In order to set up the method for analysing the bioaccessibility of pollutants in soil samples in the Laboratory for the analysis of geological materials at the Department of Mineralogy, Petrology and Mineral resources (Faculty of Mining, Geology and Petroleum Engineering, University of Zagreb - RGNF), with regards to the available equipment, an orientation survey was carried out in collaboration with the Department of Biochemical Engineering (Faculty of Food Technology and Biotechnology, University of Zagreb - PBF). The digestion of two different samples in synthetic fluids (gastric and intestinal fluid) was performed simultaneously at the RGNF laboratory and PBF laboratory under different extraction conditions according to each laboratory's ability. Prior to the analysis of bioaccessibility, detailed mineralogical and chemical characterization of the samples was performed. The comparison of two experiments showed that there is a relatively good correlation between concentrations obtained after digestion of the samples in different laboratories, under different conditions. As a result of this study, an efficient and relatively inexpensive method for determining bioaccessibility was set up at Faculty of Mining, Geology and Petroleum Engineering, which makes this kind of test more accessible and enables a new approach in risk assessment studies.
\end{abstract}

\section{Keywords}

bioaccessibility, ingestion, health assessment, potentially toxic elements, polluted soil

\section{Introduction}

One of the major exposure routes for potentially toxic elements (PTEs) in soil/sediment is through ingestion. A crucial step in the estimation of bioavailability and evaluation of the risk to human health is the measurement of the oral bioaccessibility of a pollutant, defined as the fraction that is soluble in the gastrointestinal tract and is available for absorption (Paustenbach, 2000). Bioaccessibility is commonly confused in the literature with bioavailability, which is defined by toxicologists to be the fraction of an administered dose of a toxicant that is absorbed via an exposure route, reaches the bloodstream, and is transported in the body to a site of toxicological action (Plumlee et al., 2006). A number of laboratory based in vitro tests which mimic the biochemical conditions in the human gastrointestinal tract are used to assess the degree of metal solubility i.e. oral bioaccessibility (DIN, 2000, Rodriguez et al., 1999, Hamel et al., 1999, Hamel, 1998, Medlin, 1997, Rotard et al., 1995, Ruby et al., 1993, Molly et al., 1993, XII, 1990) (reviewed in (Dean and Ma, 2007, Intawongse and Dean, 2006, Wragg and Cave, 2003). The human gastrointestinal tract consists of a number of compartments where ingested soil/sediment undergoes a series of reactions in which fluid composition, $\mathrm{pH}$ and reaction time all vary. The analogue digestive tract methods use extractions that mimic a combination of one or more of the compartments (Oomen et al., 2002). These methods can be divided into two types: 1) the batch test, where the sample and reagents are reacted in a single container with additional chemicals being added and samples removed as 
stated in each specified protocol, and 2) the flow through a reactor system, in which the reaction takes place under flowing conditions, designed to simulate the actual transit characteristics of the gastrointestinal tract (Wragg and Cave, 2003).

As reported in several reviews (Dean and Ma, 2007, Intawongse and Dean, 2006, Wragg and Cave, 2003), the most commonly used batch extraction methods are as follows: the physiologically based extraction test (PBET) originally developed by Ruby et al. (1993); the in vitro gastrointestinal method (IVG) (Rodriguez et al., 1999); the Dutch National Institute for Public Health and the Environment method (RIVM) (Versantvoort and Rompelberg, 2004) and the relative bioaccessibility leaching procedure (RBALP) (Drexler and Brattin, 2007, Drexler, 1999). The Bioaccessibility Research Group of Europe (BARGE) developed in vitro physiologically based ingestion bioaccessibility procedure for soils, based on the RIVM methodology, known as the Unified BARGE Method (UBM) (Wragg et al., 2011). In vitro gastrointestinal protocols provide a rapid and inexpensive means to determine the bioaccessibility of a given potentially toxic element present in soil and represent appropriate alternatives to animal testing.

In order to set up the method for analysing bioaccessibility of pollutants in soil samples in the Laboratory for the analysis of geological materials at the Department of Mineralogy, Petrology and Mineral resources (Faculty of Mining, Geology and Petroleum Engineering, University of Zagreb - RGNF), with regards to the available equipment, an orientation survey was carried out in collaboration with the Department of Biochemical Engineering (Faculty of Food Technology and Biotechnology, University of Zagreb - PBF).

The digestion of two different samples in synthetic fluids (gastric and intestinal fluid) was performed simultaneously at the RGNF laboratory and the PBF laboratory under different extraction conditions according to each laboratory's ability. Prior to the analysis of bioaccessibility, detailed mineralogical and chemical characterization of the samples was performed.

\section{Materials and Methods}

Two different types of samples were used in this study: (1) residential soil; and (2) tailings. The analysed samples were collected in the area of an abandoned lead-zinc-vanadium mine Berg Aukas in Namibia.

Samples were air dried and sieved to fraction $<250 \mu \mathrm{m}$, because this particle size is representative of that which adheres to children's hands (Agency, 2008). Mineral content of the samples was determined using X-ray diffraction (Philips diffractometer PW1710). In addition to the body fluids extraction, pseudo-total metal content (aqua regia extraction) as well as sequential extraction were performed. All extracts were analysed using flame atomic absorption spectroscopy (AAnalyst 700 Perkin Elmer). Samples with analytical methods performed are listed in Table 1.

Table 1 Studied samples and analyses

\begin{tabular}{lccc}
\hline Sample label & Sample type & XRD & Extraction type* \\
\hline $\mathbf{4 5 7 8}$ & tailings & + & XRD, AR, SEA, BF \\
$\mathbf{4 5 9 0}$ & soil & + & XRD, AR, SEA, BF \\
\hline \multicolumn{4}{r}{ *XRD - X-ray diffraction, AR - aqua regia extraction, } \\
SEA - sequential extraction, BF - body fluids extractions
\end{tabular}

\subsection{Aqua regia extraction}

The pseudo-total $\mathrm{Cd}, \mathrm{Cu}, \mathrm{Pb}$ and $\mathrm{Zn}$ contents were obtained by a standardized aqua regia extraction protocol according to ISO Standard 11466 (ISO, 1995). Aqua regia soluble metal concentrations in analysed soil and tailings were compared with the Canadian Soil Quality Guidelines (CCME, 1999). 


\subsection{Sequential extraction}

Different binding sites of metals in samples were analysed using sequential extraction, whereby a series of single reagents areused to extract operationally-defined phases (the selectivity depends on such factors as chemicals employed, the time and nature of contact, and the sample to volume ratio) in a defined sequence from $1 \mathrm{~g}$ of the sample. BCR (Community Bureau of Reference) sequential extraction procedure (Rauret et al., 2001) was used to give four fractions (Table 2): (1) acid (bound to carbonates); (2) reducible (bound to iron and manganese oxides, hydroxides and oxyhydroxides); (3) oxidisable (bound to organic matter and/or sulphides); and (4) residual (bound to chemically resistant minerals).

Table 2 The BCR sequential extraction procedure (Rauret et al., 2001)

\begin{tabular}{|c|c|c|c|}
\hline $\begin{array}{c}\text { Step } \\
\text { number }\end{array}$ & Fraction & Label & Reagent/concentration/pH \\
\hline 1 & $\begin{array}{l}\text { Exchangeable, } \\
\text { acid-and } \\
\text { water-soluble }\end{array}$ & CARB & $\begin{array}{l}\text { Acetic acid } \\
\mathrm{CH}_{3} \mathrm{COOH}(0.11 \mathrm{~mol} / \mathrm{L})\end{array}$ \\
\hline 2 & Reducible & FEMN & $\begin{array}{l}\text { Hydroxylammonium chloride } \\
\mathrm{NH}_{2} \mathrm{OH} \times \mathrm{HCl}(0.5 \mathrm{~mol} / \mathrm{L}) \\
\mathrm{pH} 2\end{array}$ \\
\hline 3 & Oxidisable & OR/SUL & $\begin{array}{l}\text { Hydrogen peroxide } \\
\mathrm{H}_{2} \mathrm{O}_{2}(8.8 \mathrm{~mol} / \mathrm{L}) \\
\mathrm{Ammonium} \mathrm{acetate} \\
\mathrm{NH}_{4} \mathrm{OOCCH}_{3}(1.0 \mathrm{~mol} / \mathrm{L}) \\
\mathrm{pH} 2\end{array}$ \\
\hline 4 & Residual & RES & $\begin{array}{l}\text { Aqua regia: } \\
\text { Hydrochloric acid } \\
\mathrm{HCl}(12.0 \mathrm{~mol} / \mathrm{L}) \\
\mathrm{Nitric} \text { acid } \\
\mathrm{HNO}_{3}(15.8 \mathrm{~mol} / \mathrm{L})\end{array}$ \\
\hline
\end{tabular}

\subsection{Body fluids extractions}

Simulated gastric and intestinal fluids were prepared according to Kos and Goreta (2000), with some modifications. Briefly, simulated gastric fluid was prepared by dissolving pepsin (AppliChem, Germany) (3 g/L) in a sodium chloride solution $(0.5 \%)$ adjusting the $\mathrm{pH}$ to $1 \pm 0.2$ with concentrated $\mathrm{HCl}$. Simulated intestinal fluid was prepared by suspending pancreatin (AppliChem, Germany) $(1 \mathrm{~g} / \mathrm{L})$ and bile salts (Difco, USA) $(3 \mathrm{mg} / \mathrm{mL}$ ox gall) in a sodium chloride solution $(0.5 \%)$ and the $\mathrm{pH}$ was adjusted to 8.0 with $30 \% \mathrm{NaOH}$. Both gastric and intestinal fluids were prepared fresh.

Digestion in synthetic fluids was performed simultaneously at the RGNF laboratory and the PBF laboratory under different extraction conditions, as described below and shown in Table 3, along with an overview of the different in vitro digestion models described in the literature. For each sample, two extracts were collected: one at the end of the gastric phase and another at the end of the gastro-intestinal phase. In this study, the gastric phase (G) is a digestive extract collected after 1 hour of agitation with simulated gastric fluid. The gastro-intestinal phase (GI) is a digestive extract collected after 1 hour of agitation with gastric fluid followed by 4 hours agitation with simulated intestinal fluid. 
Table 3 Bioaccessibility test methods

\begin{tabular}{|c|c|c|c|c|c|c|}
\hline Method & Compartments* & pH & $\mathrm{T}^{\circ} \mathrm{C}$ & $\mathrm{S} / \mathrm{L}$ ratio & Residence time & Metals tested \\
\hline \multirow[t]{2}{*}{ RGNF } & $\mathrm{S}$ & 1.2 & $25-27$ & $0.5 / 18$ & $1 \mathrm{~h}$ & $\mathrm{Cd}, \mathrm{Cu}, \mathrm{Pb}, \mathrm{Zn}$ \\
\hline & SI & 8 & & $0.5 / 47$ & $4 \mathrm{~h}$ & \\
\hline \multirow[t]{2}{*}{ PBF } & $S$ & 1.2 & 37 & $0.5 / 18$ & $1 \mathrm{~h}$ & $\mathrm{Cd}, \mathrm{Cu}, \mathrm{Pb}, \mathrm{Zn}$ \\
\hline & SI & 8 & & $0.5 / 47$ & $4 \mathrm{~h}$ & \\
\hline \multirow{3}{*}{$\begin{array}{l}\text { UBM } \\
\text { (Oomen et al. 2002) }\end{array}$} & $\mathrm{OC}$ & 6.5 & 37 & $0.6 / 9$ & $10 \mathrm{~s}$ & \\
\hline & $\mathrm{S}$ & 1.1 & & $0.6 / 22.5$ & $1 \mathrm{~h}$ & $\mathrm{As}, \mathrm{Cd}, \mathrm{Pb}$ \\
\hline & SI & 7.4 & & $0.6 / 58.5$ & $4 \mathrm{~h}$ & \\
\hline \multirow{2}{*}{$\begin{array}{l}\text { PBET } \\
\text { (Ruby et al. 1996) }\end{array}$} & $\mathrm{S}$ & 2.5 & 37 & $1 / 100$ & $1 \mathrm{~h}$ & $\mathrm{As}, \mathrm{Pb}$ \\
\hline & SI & 7 & & & $4 \mathrm{~h}$ & \\
\hline $\begin{array}{l}\text { SBET } \\
\text { (Drexler 1999) }\end{array}$ & S & 1.5 & 37 & $1 / 100$ & $1 \mathrm{~h}$ & $\mathrm{As}, \mathrm{Cd}, \mathrm{Pb}$ \\
\hline \multirow{3}{*}{$\begin{array}{l}\text { DIN } \\
\text { (DIN 2000) }\end{array}$} & OC & 6.4 & 37 & $1 / 15$ & 0.5 & $\mathrm{As}, \mathrm{Cd}, \mathrm{Pb}, \mathrm{Cr}, \mathrm{Hg}$ \\
\hline & $\mathrm{S}$ & 2 & & $1 / 50$ & $2 \mathrm{~h}$ & \\
\hline & SI & 7.5 & & $1 / 100$ & $6 \mathrm{~h}$ & \\
\hline \multirow{2}{*}{$\begin{array}{l}\text { SHIME } \\
\text { (Molly et al. 1993) }\end{array}$} & S & 5.2 & 37 & $1 / 2.5$ & $3 \mathrm{~h}$ & $\mathrm{As}, \mathrm{Cd}, \mathrm{Pb}$ \\
\hline & SI & 6.5 & & $1 / 4$ & $5 \mathrm{~h}$ & \\
\hline \multirow{3}{*}{$\begin{array}{l}\text { RIVM } \\
\text { (Rotard et al. 1995) }\end{array}$} & $\mathrm{OC}$ & 6.5 & 37 & $1 / 15$ & $5 \mathrm{~min}$ & $\mathrm{As}, \mathrm{Cd}, \mathrm{Pb}$ \\
\hline & $\mathrm{S}$ & 1.1 & & $1 / 37.5$ & $2 \mathrm{~h}$ & \\
\hline & SI & 5.5 & & & $2 \mathrm{~h}$ & \\
\hline \multirow{2}{*}{$\begin{array}{l}\text { IVG } \\
\text { (Rodriguez and Basta 1999) }\end{array}$} & S & 1.8 & 37 & $1 / 150$ & $?$ & As \\
\hline & SI & 5.5 & & & $?$ & \\
\hline $\begin{array}{l}\text { US P } \\
\text { (Hamel et al. 1998) }\end{array}$ & $S$ & ca. 1 & 37 & $1 / 1000$ & $2 \mathrm{~h}$ & $\mathrm{~Pb}, \mathrm{Cr}, \mathrm{As}, \mathrm{Cd}, \mathrm{Ni}$ \\
\hline \multirow{3}{*}{$\begin{array}{l}\text { MB \& SR } \\
\text { (Hamel et al. 1999) }\end{array}$} & OC & ca. 1 & 37 & $1 / 160$ & $5 \mathrm{~s}$ & $\mathrm{~Pb}, \mathrm{Cr}, \mathrm{As}, \mathrm{Cd}$ \\
\hline & $\mathrm{S}$ & & & $1 / 2160$ & $2 \mathrm{~h}$ & \\
\hline & SI & & & $1 / 4770$ & $4 \mathrm{~h}$ & \\
\hline
\end{tabular}

*OC - Oral Cavity, S - Stomach, SI - Small Intestine

The digestion was started by suspending $0.5 \mathrm{~g}$ of dry soil sample in $18 \mathrm{~mL}$ of gastric fluid. This mixture was rotated endover-end at room temperature $\left(25-27^{\circ} \mathrm{C}\right)$ for $1 \mathrm{~h}$ at the RGNF laboratory, while agitated in a benchtop water bath shaker at $37^{\circ} \mathrm{C}$ for $1 \mathrm{~h}$ at the PBF laboratory. For the replicate samples, this was followed by an addition of $29 \mathrm{~mL}$ of intestinal fluid and agitation for another 4 hours. Subsequently, the samples of gastric and gastro-intestinal phase were centrifuged at $3800 \mathrm{rpm}$ for $10 \mathrm{~min}$ and filtered, and $67 \% \mathrm{HNO}_{3}$ was added $(0.5 \mathrm{~mL}$ and $1 \mathrm{~mL}$, respectively) to the supernatants before they were stored for analysis. The $\mathrm{pH}$ of the extracts was measured at the end of digestion for each phase. Bioaccessibility was calculated per digestion according to the following equation:

$\%$ bioaccessible $=\frac{\text { concentration of bioaccessible metal }\left(\mathrm{mg} \mathrm{kg}^{-1}\right)}{\text { concentration of total metal in sample }\left(\mathrm{mg} \mathrm{kg}^{-1}\right)} \times 100$ 


\section{Results and Discussion}

The dominant mineral in the tailings sample is dolomite, followed by calcite, quartz, willemite (zinc silicate mineral $\mathrm{Zn}_{2} \mathrm{SiO}_{4}$ ), illitic material and traces of $\mathrm{K}$-feldspar. There is indication of the presence of descloizite (lead and zinc vanadate - $\left.(\mathrm{Pb}, \mathrm{Zn})_{2}(\mathrm{OH}) \mathrm{VO}_{4}\right)$. The soil sample contains dominantly quartz, followed by calcite, dolomite and $\mathrm{K}$-feldspar.

Potentially toxic elements measured in aqua regia extracts of the samples are $\mathrm{Cd}, \mathrm{Cu}, \mathrm{Pb}$ and $\mathrm{Zn}$. Pseudo-total concentrations of PTEs in the sample of tailings are $290 \mathrm{mg} / \mathrm{kg}, 153 \mathrm{mg} / \mathrm{kg}, 10,636 \mathrm{mg} / \mathrm{kg}$ and 43,783mg/kg, while those in sample of soil are $23 \mathrm{mg} / \mathrm{kg}, 25 \mathrm{mg} / \mathrm{kg}, 1,199 \mathrm{mg} / \mathrm{kg}$ and $5,919 \mathrm{mg} / \mathrm{kg}$, respectively. Metal concentrations in the analysed soil (except $\mathrm{Cu}$ concentration) and tailings exceed Canadian Soil Quality Guidelines (CCME, 1999) which are defined as the concentrations recommended to provide a healthy, functioning ecosystem capable of sustaining the existing and likely future uses of the site by ecological receptors and humans (Table 4).

Table 4 Soil quality guidlines for the protection of environmental and human health (CCME, 1999)

\begin{tabular}{lcccc}
\hline & \multicolumn{4}{c}{ Concentration (mg/kg dry weight) } \\
\hline \multicolumn{1}{c}{ Element } & Agricultural & Residental/parkland & Commercial & Industrial \\
Cadmium & 1.4 & 10 & 22 & 22 \\
Copper & 63 & 63 & 91 & 91 \\
Lead & 70 & 140 & 260 & 600 \\
Zinc & 200 & 200 & 360 & 360 \\
\hline
\end{tabular}

Metal concentrations in aqua regia extracts cannot be the sole indicator of the environmental risk caused by polluted soil/sediment, since they can be tightly bound in a mineral lattice of minerals and although present in significant amounts do not affect the environment and human health. Hence, sequential extraction analysis was performed to determine the binding sites of the analysed metals. Distribution of metals in different soil phases, determined by sequential extraction analysis, is shown in Figure 1. It appears that approximately $20-40 \%$ of total concentration in the sample is bound in organic as well as in residual fraction for most of the analysed metals in the sample of tailings, whereas in the soil sample nearly $50 \%$ of metals are bound to organic fraction, with cadmium as an exception. The main binding sites for $\mathrm{Cd}$ are carbonate and reducible fraction.
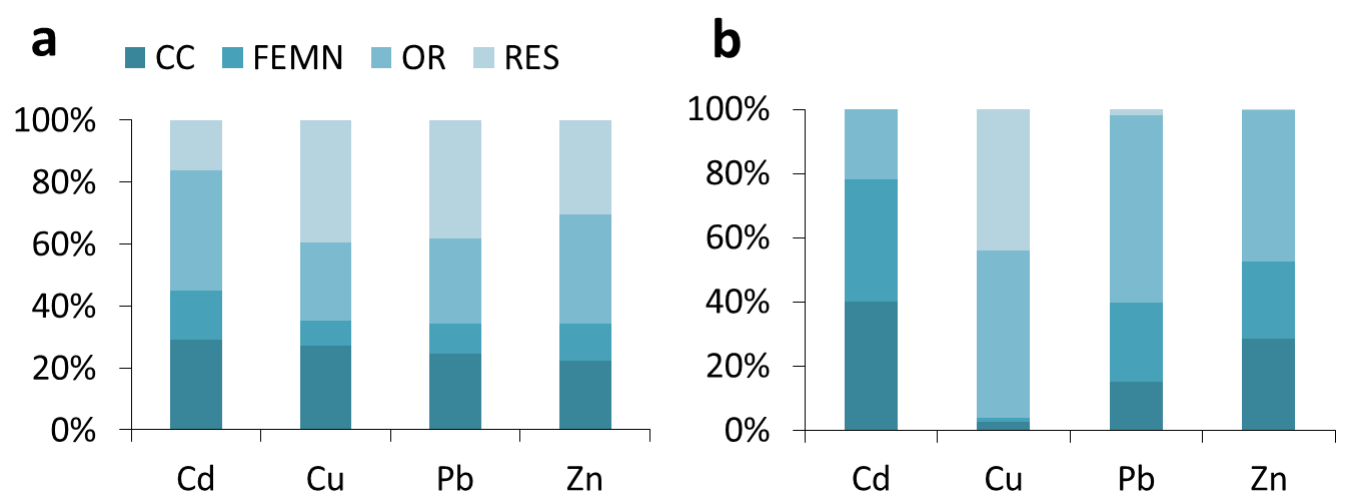

Figure 1 Distribution of cadmium, copper, lead and zinc in sequential fractions of the(a) tailings sample (4578), and (b) soil sample (459o). Legend: CC - carbonate fraction, FEMN - reducible fraction (iron and manganese oxides, hydroxides and oxyhydroxides), OR - oxidisable fraction (organic matter/sulphides), RES - residual fraction. 
To assess the possible environmental risk posed by samples, they were classified according to the Risk Assessment Code (RAC) introduced by Perin et al. (1985). It gives an indication of the available fraction of the elements by taking into account the percentage of element concentrations present in the exchangeable and carbonate fractions $(<1 \%$ no risk; $1-$ $10 \%$ low risk, $11-30 \%$ medium risk, $31-50 \%$ serious risk and $>50 \%$ high risk). The tailings pose a medium risk to the environment in regards to all measured elements, while the risk of the soil sample is low for $\mathrm{Cu}$, medium for $\mathrm{Pb}$ and serious for $\mathrm{Cd}$ and $\mathrm{Zn}$.

\subsection{Bioaccessibility of $\mathrm{Cd}, \mathrm{Cu}, \mathrm{Pb}$ and $\mathrm{Zn}$ in analysed samples}

Bioaccessible concentrations ( $\mathrm{mg} / \mathrm{kg}$ ) of $\mathrm{Cd}, \mathrm{Cu}, \mathrm{Pb}$ and $\mathrm{Zn}$ measured in the samples after digestion in simulated gastric and intestinal fluids, as part of the orientation study simultaneously carried out at RGNF and PBF, are given in Table 5. For each digestive phase, there is a relatively good correlation between concentrations obtained after digestion of samples in different labs, under different conditions. This is also obvious from Figure 2, which shows relative bioaccessibilities (\%) of measured potentially toxic elements in the samples. The concentration of lead in the gastrointestinal phase of the tailings sample is significantly lower than in the gastric phase, possibly due to poor sample homogeneity. Even so, the values obtained in different labs differ only slightly. Hence, the reported results show that it is likely that differences in the experimental design of the tests i.e. agitation procedure and temperature conditions, do not cause significant variation in the bioaccessibility values of the measured elements.

Table 5 Values of bioaccessible concentrations $(\mathrm{mg} / \mathrm{kg}$ ) of metals in the gastric (G) and gastrointestinal (GI) phases for the analysed samples measured at the Faculty of Mining, Geology and Petroleum Engineering (RGNF) and at the Faculty of Food Technology and Biotechnology (PBF).

\begin{tabular}{|c|c|c|c|c|}
\hline \multirow[t]{3}{*}{ Element } & \multicolumn{4}{|c|}{ Gastric phase } \\
\hline & \multicolumn{2}{|c|}{ (4578) tailings } & \multicolumn{2}{|c|}{ (4590) soil } \\
\hline & $R G N F$ & $P B F$ & $R G N F$ & $P B F$ \\
\hline Cd & 130 & 138 & 19 & 18 \\
\hline $\mathbf{C u}$ & 83 & 82 & 15 & 15 \\
\hline $\mathbf{P b}$ & 4,205 & 4,001 & 857 & 860 \\
\hline $\mathbf{Z n}$ & 17,447 & 18,962 & 3,678 & 3,730 \\
\hline \multirow[t]{2}{*}{ Element } & \multicolumn{4}{|c|}{ Gastro-intestinal phase } \\
\hline & $R G N F$ & $P B F$ & $R G N F$ & $P B F$ \\
\hline Cd & 146 & 152 & 18 & 19 \\
\hline $\mathbf{C u}$ & 85 & 83 & 14 & 14 \\
\hline $\mathbf{P b}$ & 1,368 & 790 & 854 & 830 \\
\hline $\mathbf{Z n}$ & 23,666 & 21,022 & 3,620 & 3,433 \\
\hline
\end{tabular}



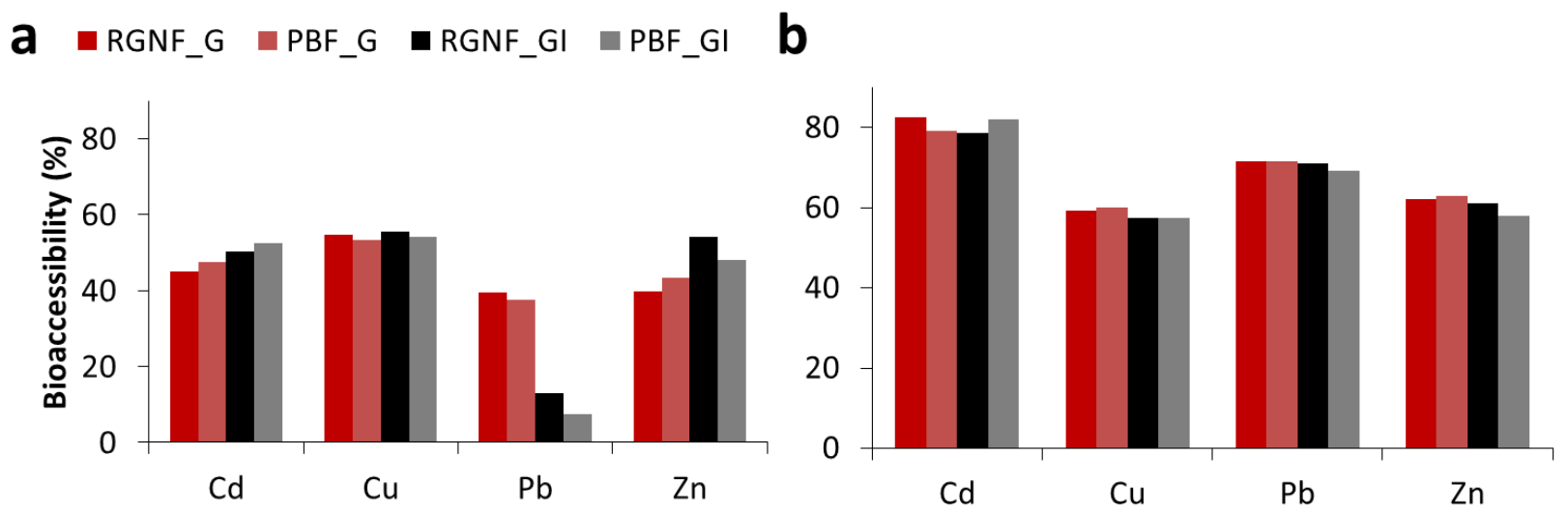

Figure 2 Relative bioaccessibility (\%) of potentially toxic elements (PTEs) in the (a) tailings sample (4578), and (b) soil sample (459o). Legend: RGNF - measured at the Faculty of Mining, Geology and Petroleum Engineering, PBF - measured at the Faculty of Food Technology and Biotechnology, G - gastric phase, GI - gastrointestinal phase.

The acidic environment of the stomach compartment causes metals to mobilize from soil, which usually causes high bioaccessibility values in this phase. However, it can be observed that values in the intestinal phase for the tailings sample are higher compared to the gastric phase, except for $\mathrm{Pb}$. This can be explained with more neutral $\mathrm{pH}$ levels of the intestinal compartment, where the metals can form new complexes. Furthermore, the $\mathrm{pH}$ values of the compartments are not fixed so they are dependent on the matrix of ingestion i.e. tailings/soil. The comparison of results of these two experiments enabled the decision to perform bioaccessibility determination at RGNF. The bioaccessibility test was repeated on samples as described previously and they were characterised in regards of their potential health risk as follows.

To estimate the potential risk of PTEs on humans, the Maximum Permissible Risk (MPR) values according to Baars et al. (2001) were quantified, herein expressed as tolerable daily intake (TDI). TDI is defined as the estimated amount of the chemical that humans can ingest daily during their entire lifetime without resultant adverse health effects. Values for the elements analysed in this study are as follows: $\mathrm{Cd}-0.5 \mathrm{~g} / \mathrm{kg} \mathrm{tt} / \mathrm{day} ; \mathrm{Cu}-140 \mu \mathrm{g} / \mathrm{kg} \mathrm{tt} / \mathrm{day} ; \mathrm{Pb}-3.6 \mu \mathrm{g} / \mathrm{kg} \mathrm{tt} / \mathrm{day} ; \mathrm{Zn}$ $-500 \mu \mathrm{g} / \mathrm{kg} \mathrm{tt} / \mathrm{day}$; furthermore recalculated for body weight of $5 \mathrm{~kg}, 10 \mathrm{~kg}, 20 \mathrm{~kg}, 30 \mathrm{~kg}$ and $40 \mathrm{~kg}$ (see Table 6). An impact of PTEs is calculated based on the assumption that a child ingests $100 \mathrm{mg}$ of soil per day by frequent hand to mouth activity, as suggested by Van Wijnen et al. (1990). Calculated values (see Table 7) were compared to the maximum daily intake. Health risk assessment of potentially toxic elements showed that the elements of greatest concern in the tailings sample are lead and cadmium, exceeding the maximum allowable daily intake for children weighing up to $40 \mathrm{~kg}$ and up to $10 \mathrm{~kg}$, respectively. The soil sample has a high bioaccessible concentration of lead which could pose a risk for children weighing up to $10 \mathrm{~kg}$.

Table 6 Tolerable daily intake (TDI) ( $\mu \mathrm{g} /$ day) for different body weights

\begin{tabular}{lcccc}
\hline \multicolumn{5}{c}{ TDI } \\
\hline $\mathbf{C d}$ & $\boldsymbol{C u}$ & $\boldsymbol{P b}$ & $\boldsymbol{Z n}$ \\
$\mathbf{1 0} \mathbf{~ k g}$ & 2,5 & 700 & 18 & 2,500 \\
$\mathbf{2 0} \mathbf{~ k g}$ & 10 & 1,400 & 36 & 5,000 \\
$\mathbf{3 0} \mathbf{~ k g}$ & 15 & 4,200 & 72 & 10,000 \\
$\mathbf{4 0} \mathbf{~ k g}$ & 20 & 5,600 & 144 & 20,000 \\
\hline
\end{tabular}


Table 7 Concentration of bioaccessible fraction of PTEs in $100 \mathrm{mg}$ of soil/tailings

\begin{tabular}{lcccc}
\hline Sample & \multicolumn{4}{c}{ Gastric fluid $(\boldsymbol{\mu g} / \mathbf{1 0 0} \mathbf{~ m g})$} \\
\hline & $\boldsymbol{C} \boldsymbol{d}$ & $\boldsymbol{C u}$ & $\boldsymbol{P b}$ & $\boldsymbol{Z n}$ \\
(4578) tailings & 7.6 & 6.7 & 265 & 1,715 \\
(4590) soil & 1.5 & 0.9 & 55 & 264 \\
& \multicolumn{5}{c}{ Gastrointestinal fluid $(\boldsymbol{\mu g} / \mathbf{1 0 0} \mathbf{~ m g )}$} \\
& $\boldsymbol{C} \boldsymbol{C}$ & $\boldsymbol{C u}$ & $\boldsymbol{P b}$ & $\boldsymbol{Z n}$ \\
(4578) tailings & 7.7 & 7.3 & 30 & 1,369 \\
(459) soil & 1.3 & 0.9 & 13 & 139 \\
\hline
\end{tabular}

\subsection{Impact of binding sites of metals on bioaccessibility}

The bioaccessibility of measured potentially toxic elements in samples was plotted in relation to the sum of their concentrations in soil/tailings fractions, obtained by sequential extraction (see Figure 3). It must be noted that the concentration of cadmium extracted by simulated body fluids from the soil sample (4590) was higher than its concentration extracted by sequential extraction, and therefore the percentage of bioaccessible $\mathrm{Cd}$ was calculated as $>$ $100 \%$ and lines excluded from the graph. It can be observed that the bioaccessible concentration of all measured elements is higher than their concentration in a carbonate fraction of samples. This leads to the conclusion that the risk assessment code (RAC) cannot be used to assess the potential risk of elements to human health, as it gives lower values compared to concentrations which are extractable in simulated body fluids. Furthermore, there is no obvious correlation between the concentration extracted by gastric fluids and the concentration in soil/tailings sequential fractions of samples. Hence, it appears that the use of the sequential extraction analysis for assessing the risk of soil/sediment ingestion on health would be a difficulty. 


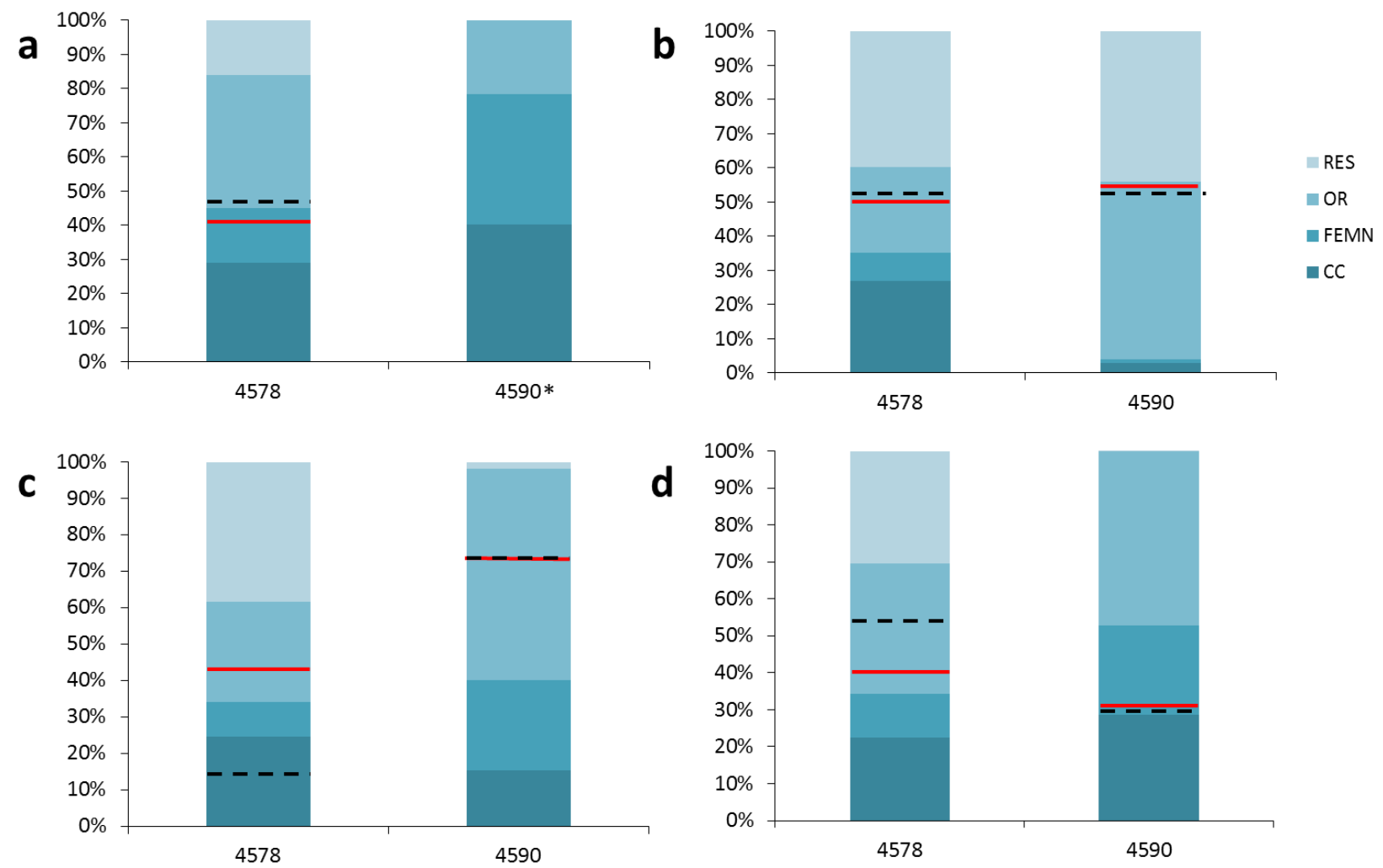

Figure 3 Bioaccessibility of potentially toxic elements (a) cadmium, (b) copper, (c) lead, and (d) zinc, following extraction in body fluids (BF) for a tailings (4578) and soil (4590) sample, in relation to the sum of their concentrations in soil fractions (CC - carbonate fraction, FEMN - reducible fraction (iron and manganese oxides, hydroxides and oxyhydroxides), OR - oxidisable fraction (organic matter/sulphides), RES - residual fraction), obtained by sequential extraction (SEA). Red line - bioaccessibility in the gastric phase $(\mathrm{G})$, black dashed line - bioaccessibility in the gastrointestinal phase (GI). ${ }^{*}$ Concentration of Cd extracted by BF from the soil sample was higher than its concentration extracted by SEA, therefore the $\%$ of bioaccessible $\mathrm{Cd}$ is $>100 \%$ and lines are excluded from the graph.

\section{Conclusion}

In conclusion, the comparison of these two experiments enabled the decision to perform bioaccessibility determination at RGNF. As a result of this study, an efficient and relatively inexpensive method for determining the bioaccessibility was set up at the Faculty of Mining, Geology and Petroleum Engineering, which makes this kind of test more accessible and enables a new approach to risk assessment studies.

\section{References}

AGENCY, U. E. P. 2008. Child-specific exposure factors handbook. Office of Research and Development, US Environmental Protection Agency Washington, DC.

BAARS, A., THEELEN, R., JANSSEN, P., HESSE, J., MEIJERINK, M., VERDAM, L. \& ZEILMAKER, M. 2001. Reevaluation of human-toxicological maximum permissible risk levels.

BARGE. Unified Bioaccessibility Method (UBM) [Online]. Available: http://www.bgs.ac.uk/barge/home.html [Accessed 14 July 2015].

CCME 1999. Canadian soil quality guidelines for the protection of environmental and human health: Summary tables. Canadian environmental quality guidelines, Canadian Council of Ministers of the Environment, Winnipeg.

DEAN, J. R. \& MA, R. 2007. Approaches to assess the oral bioaccessibility of persistent organic pollutants: a critical review. Chemosphere, 68, 1399-1407. 
DIN, D. I. F. N. E. V. 2000. Soil Quality - Absorption availability of organic and inorganic pollutants from contaminated soil material. DIN E 19738.

DREXLER, J. 1999. Standard Operating Procedure for In-vitro bioaccesibility leaching. University of Colorado at Boulder.

DREXLER, J. \& BRATTIN, W. 2007. An in vitro procedure for estimation of lead relative bioavailability: with validation. Human and Ecological Risk Assessment, 13, 383-401.

HAMEL, S. C., ELLICKSON, K. M. \& LIOY, P. J. 1999. The estimation of the bioaccessibility of heavy metals in soils using artificial biofluids by two novel methods: mass-balance and soil recapture. Science of the Total Environment, 243, 273-283.

HAMEL, S. L. C. 1998. The Estimation of Bioaccessibility of Heavy Metals in Soils Using Artificial Biofluids.

INTAWONGSE, M. \& DEAN, J. R. 2006. In-vitro testing for assessing oral bioaccessibility of trace metals in soil and food samples. TrAC Trends in Analytical Chemistry, 25, 876-886.

ISO 1995. 11466. Soil quality - Extraction of trace elements soluble in aqua regia.

KOS, B. \& GORETA, J. 2000. Effect of protectors on the viability of Lactobacillus acidophilus M92 in simulated gastrointestinal conditions. Food Technology and Biotechnology, 38, 121-127.

MEDLIN, E. A. 1997. An in vitro method for estimating the relative bioavailability of lead in humans.

MOLLY, K., WOESTYNE, M. V. \& VERSTRAETE, W. 1993. Development of a 5-step multi-chamber reactor as a simulation of the human intestinal microbial ecosystem. Applied Microbiology and Biotechnology, 39, $254-258$.

OOMEN, A. G., HACK, A., MINEKUS, M., ZEIJDNER, E., CORNELIS, C., SCHOETERS, G., VERSTRAETE, W., VAN DE WIELE, T., WRAGG, J. \& ROMPELBERG, C. J. 2002. Comparison of five in vitro digestion models to study the bioaccessibility of soil contaminants. Environmental science \& technology, 36, 3326-3334.

PAUSTENBACH, D. J. 2000. The practice of exposure assessment: a state-of-the-art review. Journal of Toxicology and Environmental Health Part B: Critical Reviews, 3, 179-291.

PERIN, G., CRABOLEDDA, L., LUCCHESE, M., CIRILLO, R., DOTTA, L., ZANETTE, M. \& ORIO, A. 1985. Heavy metal speciation in the sediments of northern Adriatic Sea. A new approach for environmental toxicity determination. Heavy metals in the environment, 2, 454-456.

PLUMLEE, G. S., MORMAN, S. A. \& ZIEGLER, T. L. 2006. The toxicological geochemistry of earth materials: an overview of processes and the interdisciplinary methods used to understand them. Reviews in Mineralogy and Geochemistry, 64, 5-57.

RAURET, G., LÓPEZ - SÁNCHEZ, J. F., LÜCK, D., YLI - HALLA, M., MUNTAU, H. \& QUEVAUVILLER, P. H. 2001. The certification of the extractable contents (mass fractions) of $\mathrm{Cd}, \mathrm{Cr}, \mathrm{Cu}, \mathrm{Ni}, \mathrm{Pb}$ and $\mathrm{Zn}$ in freshwater sediment following sequental extraction procedure BCR-701. European Commision, Belgium. ISBN 92-8940755-7.

RODRIGUEZ, R. R., BASTA, N. T., CASTEEL, S. W. \& PACE, L. W. 1999. An in vitro gastrointestinal method to estimate bioavailable arsenic in contaminated soils and solid media. Environmental Science \& Technology, 33, 642-649.

ROTARD, W., CHRISTMANN, W., KNOTH, W. \& MAILAHN, W. 1995. Determination of the absorption availability of PCDD/PCDF from'Kieselrot'(red-slag) in the digestive tract-simulation of the digestion of technogenic soil. UWSF-Z. Umweltchem. Okotox, 7, 3-9.

RUBY, M. V., DAVIS, A., LINK, T. E., SCHOOF, R., CHANEY, R. L., FREEMAN, G. B. \& BERGSTROM, P. 1993. Development of an in vitro screening test to evaluate the in vivo bioaccessibility of ingested mine-waste lead. Environmental science \& technology, 27, 2870-2877.

VAN WIJNEN, J., CLAUSING, P. \& BRUNEKREEF, B. 1990. Estimated soil ingestion by children. Environmental research, 51, 147-162.

VERSANTVOORT, C. \& ROMPELBERG, C. 2004. Development and applicability of an in vitro digestion model in assessing the bioaccessibility of contaminants from food.

WRAGG, J. \& CAVE, M. 2003. In-vitro methods for the measurement of the oral bioaccessibility of selected metals and metalloids in soils: a critical review, Environment Agency.

WRAGG, J., CAVE, M., BASTA, N., BRANDON, E., CASTEEL, S., DENYS, S., GRON, C., OOMEN, A., REIMER, K. \& TACK, K. 2011. An inter-laboratory trial of the unified BARGE bioaccessibility method for arsenic, cadmium and lead in soil. Science of the Total Environment, 409, 4016-4030.

XII, U. 1990. The United States Pharmacopoeia XXII. US Pharmacopoeial convention. 


\section{Acknowledgments}

Laboratory work was sponsored by Department of Mineralogy, Petrology and Mineral Resources of Faculty of Mining, Geology and Petroleum Engineering, University of Zagreb, Croatia. We thank Prof Blaženka Kos, Dr Jagoda Šušković and Prof Jasna Beganović from Department of Biochemical Engineering (Faculty of Food Technology and Biotechnology, University of Zagreb) for assistance in preparation of simulated body fluids.

\section{Sažetak}

\section{Procjena utjecaja ingestije zagađenoga tla/sedimenta na zdravlje}

Potencijalno toksični elementi (PTE) prijetnja su ljudskomu zdravlju jer lako mogu ući u ljudski organizam preko zagađenoga tla/sedimenta. Kako bi se procijenila biopristupačnost i utjecaj na ljudsko zdravlje, krucijalno je mjerenje oralne biopristupačnosti zagađivala. Biopristupačnost je definirana kao udio u tijelo unesene toksične tvari iz nekoga materijala koja se izlužila u tjelesnim tekućinama i dostupna je za apsorpciju u organizmu. U tu svrhu mogu se koristiti različiti laboratorijski in vitro testovi koji simuliraju ljudski probavni sustav. Oni omogućavaju brzo i povoljno određivanje biopristupačnosti te su odgovarajuća alternativa testiranju na životinjama. S ciljem uvođenja metode za analizu biopristupačnosti zagađivala u uzorcima tla u Laboratoriju za analizu geoloških materijala u Zavodu za mineralogiju, petrologiju i mineralne sirovine (Rudarsko-geološko-naftni fakultet, Sveučilište u Zagrebu - RGNF), uzimajući u obzir raspoloživu laboratorijsku opremu, izvedeno je orijentacijsko istraživanje u suradnji sa Zavodom za biokemijsko inženjerstvo (Prehrambeno-biotehnološki fakultet, Sveučilište u Zagrebu - PBF). Izluživanje dvaju različitih uzoraka u sintetičkim tekućinama (želučanoj i crijevnoj tekućini) izvedeno je istovremeno u obama laboratorijima pod različitim uvjetima ekstrakcije prema mogućnostima laboratorija. Obavljena je i detaljna mineraloška i kemijska karakterizacija uzoraka. Mineralni sastav uzoraka određen je rendgenskom difrakcijom. Osim izluživanja u tjelesnim tekućinama uzorci su otapani u zlatotopci kako bi se odredila ukupna koncentracija potencijalno toksičnih elementa, dok je za identifikaciju glavnih mjesta vezanja metala u tragovima u različitim mineraloškim frakcijama uzorka korištena sekvencijska ekstrakcijska analiza. Elementi u tragovima analizirani su u ekstraktima metodom plamene atomske apsorpcijske spektrometrije. Usporedba dvaju eksperimenata izvedenih sa sintetičkim tekućinama pokazala je da postoje neznatna odstupanja između koncentracija dobivenih nakon izluživanja uzoraka u različitim laboratorijima, pod različitim uvjetima. Kao rezultat ovoga istraživanja na Rudarsko-geološko-naftnome fakultetu uvedena je efikasna i relativno jeftina metoda za određivanje biopristupačnosti, koja čini ovu vrstu testa pristupačnijom i omogućuje novi pristup u studijama rizika za okoliš i zdravlje od zagađivala.

\section{Ključne riječi}

biopristupačnost, ingestija, procjena utjecaja na zdravlje, potencijalno toksični elementi, zagađeno tlo 
